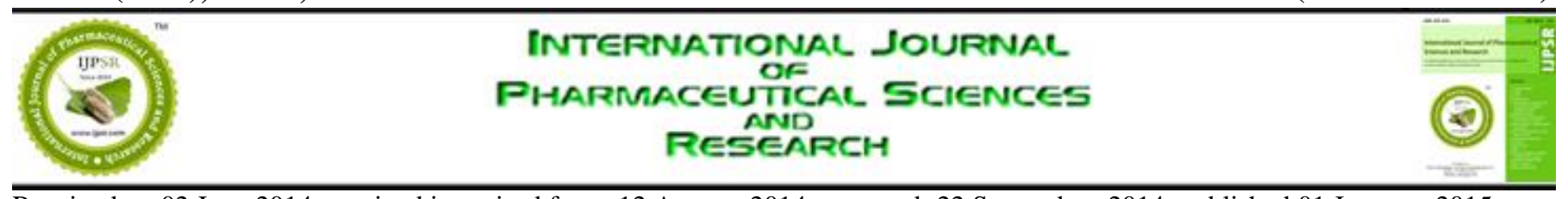

Received on 02 June 2014; received in revised form, 12 August, 2014; accepted, 22 September, 2014; published 01 January, 2015

\title{
FACILE SPECTROPHOTOMETRIC DETERMINATION OF METRONIDAZOLE AND SECNIDAZOLE IN PHARMACEUTICAL PREPARATIONS BASED ON THE FORMATION OF DYES
}

\author{
Ahmed K. Youssef, Magda M. S. Saleh, Doaa A. Abdel-Kader and Elham Y. Hashem* \\ Chemistry Department, Faculty of Science, Assiut University, 71516 Assiut, Egypt
}

Keywords:

Spectrophotometry, Metronidazole, Secnidazole, Diazotization, naphthylamine, 2,5-Dihydroxy $\alpha$ - Benzoic Acid

\section{Correspondence to Author:}

Prof. (Dr.) Elham Y. Hashem

Department of Analytical Chemistry, Chemistry Department, Faculty of Science, Assiut University, 71516 Assiut, Egypt.

E-mail: elham_hashem@yahoo.com

ABSTRACT: A rapid and sensitive spectrophotometric method is proposed for the determination of Metronidazole and Secnidazole drugs. The method depends on the reduction of Metronidazole and Secnidazole molecules with zinc dust and hydrochloric acid followed by diazotization and coupling with $\alpha$-naphthylamine to give red colored chromogens easily measured spectrophotometrically at $\lambda_{\max }=510 \mathrm{~nm}$ or coupling with 2,5-dihydroxy benzoic acid at $\lambda_{\max }=518 \mathrm{~nm}$. The Sandell's sensitivity, the molar absorptivity, correlation coefficient and the regression equation were calculated. Under optimized experimental conditions Beer's law is obeyed in the concentration range 3-30 and $2-12 \mu \mathrm{g} / \mathrm{ml}$ for Secnidazole and Metronidazole; respectively with $\alpha$-naphthyl amine as a coupling agent. Also, by using 2, 5-dihydroxybenzoic acid as a coupling agent, the concentrations obtained were $5-50 \mu \mathrm{g} / \mathrm{ml}$ for both Secnidazole and Metronidazole. Both techniques were applied successfully for the analysis of Metronidazole and Secnidazole in tablets form. These methods are recommended for quality control and routine analysis where time, cost effectiveness and high specificity of analytical techniques are of great importance.

INTRODUCTION: Nitroimidazoles are a class of veterinary drugs used for the treatment and prevention of certain bacterial and protozoal diseases in poultry as well as for swine dysentery. Their main compounds include metronidazole (MNZ), ornidazole (ONZ) and secnidazole (SNZ) 1 . Metronidazole (2-methyl-5- nitroimidazole - 1 ethanol) and secnidazolel - (2-mehyl - 5 nitroimidazole -1 - yl propan - 2 - ol) are used as antiprotozoal, antiamebic and antibacterial drugs ${ }^{2}$. Excellent reviews have been published on the activity and pharmacokinetics of these drugs.

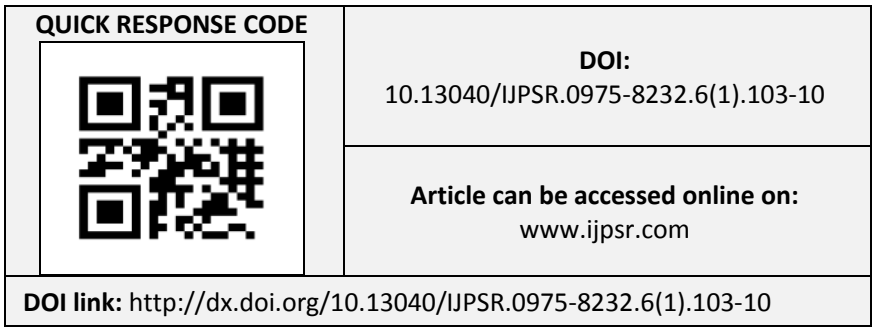

Recently, spectrophotometric methods have been widely used in pharmaceutical analysis successfully ${ }^{3}$. Several methods have been reported for determination of both Metronidazole and Secnidazole which includes potentiometric ${ }^{4,5}$, polarographic 6, 7, CPG ${ }^{8}$, supercritical Fluid Chromatography '9, TLC 10, HPLC 11-14 Voltammetric $^{15}$, derivative spectrophotometry ${ }^{16-18}$ flow injection analysis ${ }^{19}$ and Spectrophotometry ${ }^{20-}$ 30 .

Most of the spectrophotometric methods reported suffer from the disadvantage, like narrow range of determination, requires heating or extraction, long time for the reaction to complete, use of nonaqueous systems and stability of the colored product formed, etc. The purpose of our present investigation is to develop and validate a new simple, selective accurate and rapid 
spectrophotometric assay for the determination of Metronidazole and Secnidazole in either pure form or in its pharmaceutical formulations. The method is based on the reduction of Metronidazole and Secnidazole molecules with zinc dust and hydrochloric acid followed by diazotization and coupling with coupling agents 2, 5dihydroxybenzoic acid or $\alpha$-naphthyl amine.

The advantages of the present work that the reagents used are easily available and the chemistry of these reagents is already well established. The reactions involved with these reagents are simple, rapid and sensitive in the range of determination compared with other established spectrophotometric methods. The present work which gives thoroughly comparable data is simple, accurate, rapid and precise. The common excipients used as additives in pharmaceuticals do not interfere in the proposed methods.

\section{MATERIALS AND METHODS:}

Apparatus

- An evolution $300 \quad$ UV-VIS. spectrophotometer with $1.0 \mathrm{~cm}$ matched cells fitted with Vision Pro software of Thermo Electron Corporation (Cambridge, UK) was used for electronic spectral measurements.

- To obtain $\mathrm{pH}$ readings throughout the experimentation, a microprocessor $\mathrm{pH}$ meter (HANNA HI 211) was used.

\section{MATERIALS AND REAGENTS:}

All chemicals used were of analytical - reagent grade. $\alpha$-naphthylamine and 2, 5-dihydroxybenzoic acid were purchased from Sigma. Metronidazole and Secnidazole were obtained from Aldrich Company. Sodium nitrite and sodium hydroxide was purchased from prolabo. All other reagents and solvent were of analytical-reagent grade.

\section{Standard Solutions:}

Accurately (100 mg) Metronidazole or Secnidazole was transferred to a $100 \mathrm{ml}$ beaker. $1 \mathrm{~g}$ of zinc dust was added along with $20 \mathrm{ml}$ of $1 \mathrm{M}$ hydrochloric acid. The solution was stirred and left for 1 hour at room temperature. The filtrate was diluted with water to $100 \mathrm{ml}$ in a volumetric flask. The working standard solution of the reduced Metronidazole and
Secnidazole containing $100 \mu \mathrm{g} / \mathrm{ml}$ was prepared by further dilution. A $1 \% \alpha$-naphthylamine or $1 \% 2$, 5-dihydroxybenzoic acid in $1 \mathrm{M} \mathrm{HCl}$ and $10 \%$ sodium hydroxide solution were kept in amberglass volumetric flasks. A $1 \%$ sodium nitrite solution was prepared separately in double distilled water.

\section{General Procedure:}

Aliquots of the working standard solution of reduced Metronidazole or Secnidazole were transferred into $10 \mathrm{ml}$ calibrated flasks. 1 milliliter of $1 \mathrm{M} \mathrm{HC1}$ was added, cooled in an ice bath then $1 \mathrm{ml}$ of $1 \% \mathrm{NaNO}_{2}$ was added. The solution was stirred for 2 minutes and $1 \mathrm{ml}$ of $1 \% \alpha$ naphthylamie, $1.5 \mathrm{ml}$ of $\mathrm{NaOH}$ and $3 \mathrm{ml}$ of absolute ethanol was added then the solution was diluted using double distilled water.

While, the above procedure was carried out in case of 2, 5-dihydroxybenzoic acid as described. Aliquots of the working standard solution of reduced Metronidazole or reduced Secnidazole were transferred into $10 \mathrm{ml}$ calibrated flasks, $1.5 \mathrm{ml}$ of $1 \mathrm{M} \mathrm{HC} 1$ was introduced then $1 \mathrm{ml}$ of $1 \%$ $\mathrm{NaNO}_{2}$ was added after cooling in an ice bath. The solution was stirred for $2 \mathrm{~min}$. and $1 \mathrm{ml}$ of $1 \% 2$, 5 dihydroxybenzoic acid, $1 \mathrm{ml}$ of $10 \% \mathrm{NaOH}$ and 2 $\mathrm{ml}$ of absolute ethanol was added then the solution was diluted using double distilled water.

\section{Analysis of Pharmaceutical Preparations:}

Ten tablets were powdered and mixed thoroughly. An amount equivalent to $100 \mathrm{mg}$ of the drug was reduced as mentioned before and the filtrate was made up to $100 \mathrm{ml}$ and an aliquot of this solution was treated as described above for pure sample. The amount of each drug was calculated from the calibration graph.

\section{Interferences from Excipients:}

The effect of interfering common excipients such as uric acid, vitamin $\mathrm{C}$, glucose, carboxy methyl cellulose and lactose on $50 \mathrm{mg}$ Metronidazole or 50 mg Secnidazole was studied. The procedure was carried out as described under general procedure.

\section{RESULTS AND DISCUSSION:}

Metronidazole and Secnidazole showed weak absorption bonds in UV-range. For this reason, the proposed spectrophotometric method for the 
determination of Metronidazole and Secnidazole is based on the reduction of the nitro group to an amino group with zinc dust and hydrochloric acid followed by diazotization and coupling with 2, 5dihydroxbenzoic acid or with $\alpha$-naphthylamine to give red colored products.

\section{Spectral characteristics and Reaction} Mechanism:

The absorption spectra of the red colored product with $\lambda_{\max }=510 \mathrm{~nm}$ in case of $\alpha$-naphthylamine or with $\lambda_{\max }=518 \mathrm{~nm}$ in case of 2, 5-dihydroxybenzoic acid. The stability of colored azo products lasts for 3 days in case of $\alpha-$ naphthylamine or 2, 5-dihydroxybenzoic acid compared with 2 days in case of $\beta$-naphtol as reported in literature ${ }^{29}$. Indicating high stability of colored azo products for our proposed methods. The absorption spectra of reduced form of Metronidazole and the spectrum of the red azo product obtained at $\lambda_{\max }=518 \mathrm{~nm}$ were showed in Figure 1. The reagent blank has practically negligible absorption at this wave length.

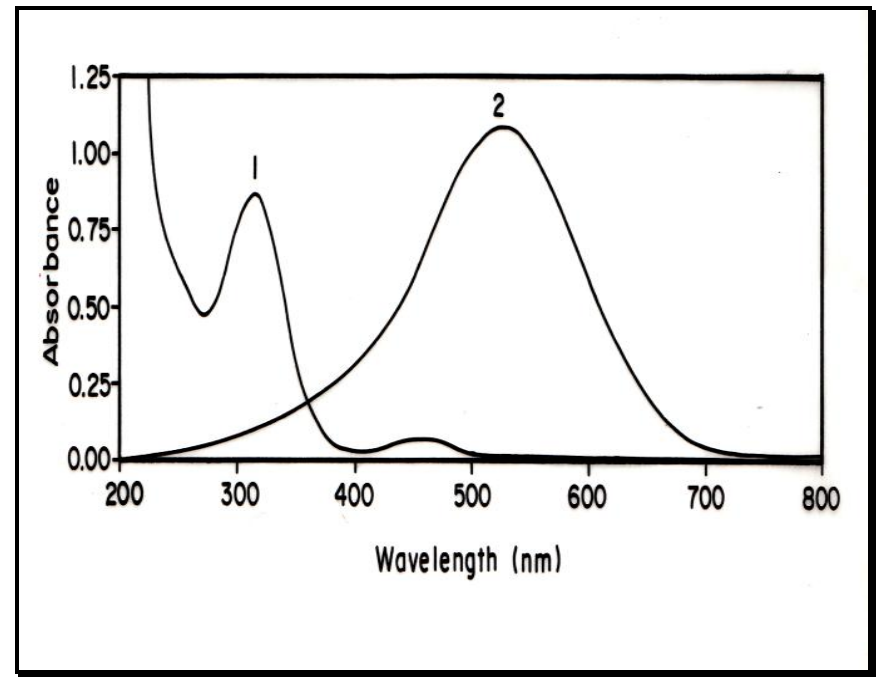

FIGURE 1: ABSORPTION SPECTRA OF $40 \mu \mathrm{g} / \mathrm{ml}$ METRONIDAZOLE DRUG IN THE REDUCED FORM (1) AND THE SPECTRUM OF THE RED AZO PRODUCT OBTAINED (2) IN PRESENCE OF $0.5 \mathrm{ml}$ OF $1 \mathrm{M}$ HCl, $1 \mathrm{ml}$ OF $2 \%$ 2, 5-DIHYDROXYBENZOIC ACID, $1.5 \mathrm{ml}$ OF $20 \%$ NaOH, 2ml ETHANOL AND $1 \mathrm{ml}$ OF $2 \% \mathrm{NaNO}_{2}$ AT $25^{\circ} \mathrm{C}$

The stoichiometric equations derived were shown in schemes $\mathbf{1}$ and $\mathbf{2}$.

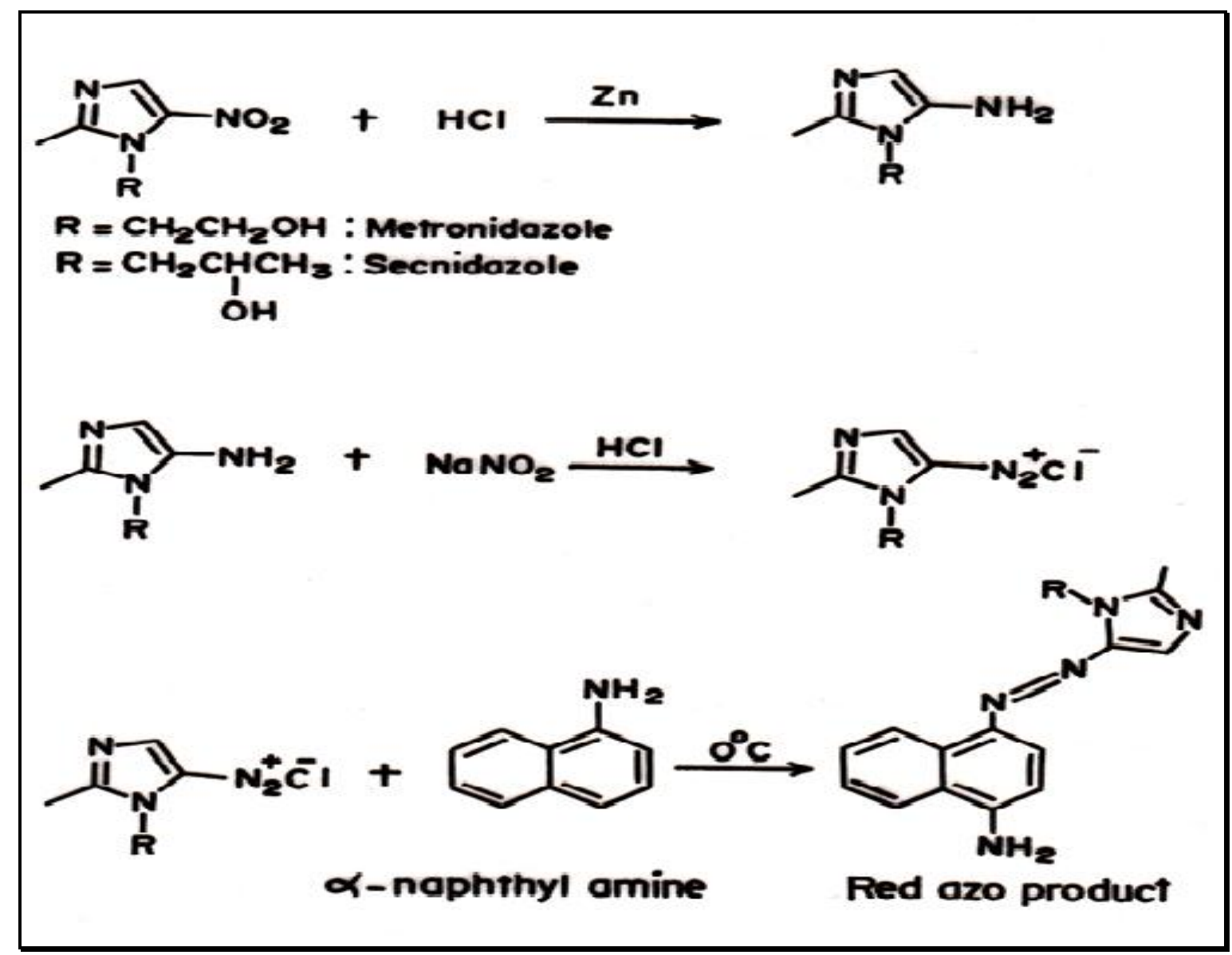

SCHEME 1: REACTION SEQUENCE FOR THE FORMATION OF AZO COLORED PRODUCT USING $\alpha$-NAPHTHYL AMINE AS COUPLING AGENT 


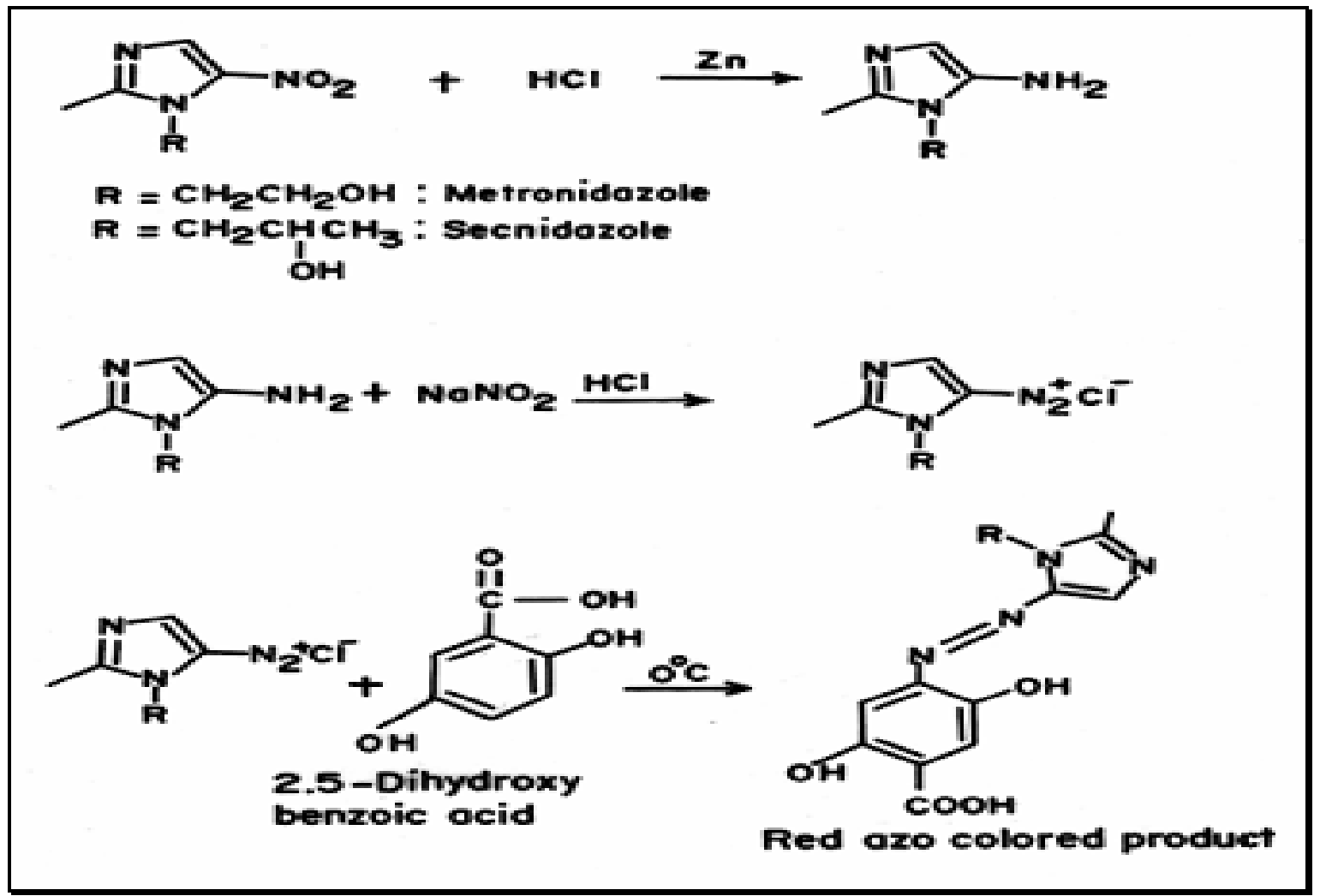

SCHEME 2: REACTION MECHANISM FOR THE FORMATION OF AZO COLORED PRODUCT USING 2, 5DIHYDROXYBENZOIC ACID AS COUPLING AGENT

\section{Optimization of reaction conditions}

In order to optimize the conditions, we have investigated number of parameters such as the coupling agent concentrations, effect of $\mathrm{HCl}$, effect of $\mathrm{NaNO}_{2}$ and effect of $\mathrm{NaOH}$ as shown in Figure 2. The optimal conditions were established by changing one variable and observing its effect on the absorbance of the colored product. The investigations were carried out to achieve maximum color development in the quantitative determination of studied drugs. The factors affecting color development reproducibility,

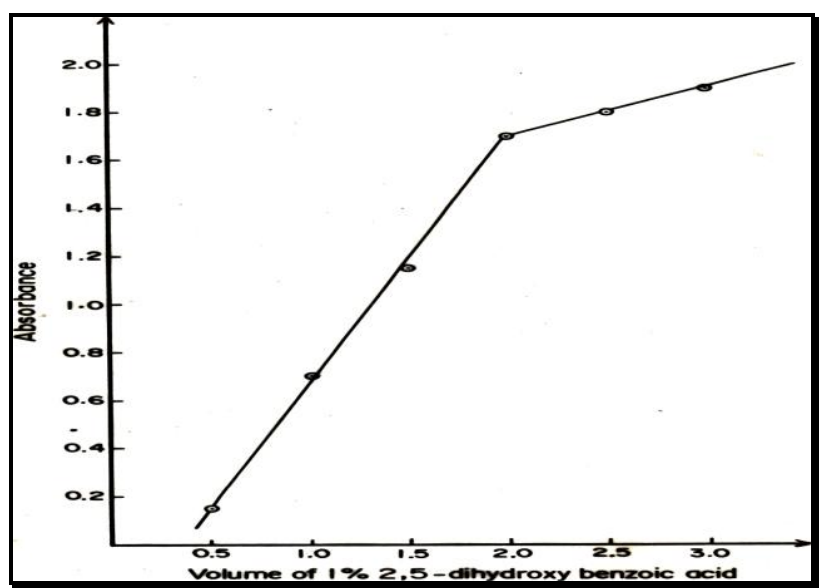

A- EFFECT OF VOLUME OF $1 \%$ 2, 5-DIHYDROXY BENZOIC ACID sensitivity and conformity with Beer's law were studies. It was found that, $0.5-3 \mathrm{ml}$ of $1 \mathrm{M} \mathrm{HC} 1$, $0.2-1.5 \mathrm{ml}$ of $1 \% \mathrm{NaNO}_{2}$ solution, $0.4-2 \mathrm{ml}$ of $\alpha-$ naphthylamine $1 \%, 0.5-2.5 \mathrm{ml}$ of $10 \% \mathrm{NaOH}$ solution were necessary in case of $\alpha$-naphthylamine as coupling agent. While, the use of 2,5-dihydroxy benzoic acid as a coupling agent required, 0.5-2.0 $\mathrm{ml}$ of $1 \mathrm{M} \mathrm{HC} 1,0.5-3 \mathrm{ml}$ of $1 \% \mathrm{NaNO}_{2}$ solution, $0.5-2.5 \mathrm{ml}$ of $1 \%$ dihydroxy benzoic acid , 1-3 ml of $10 \% \mathrm{NaOH}$ solution to achieve maximum colour intensity as shown in Figure 2.

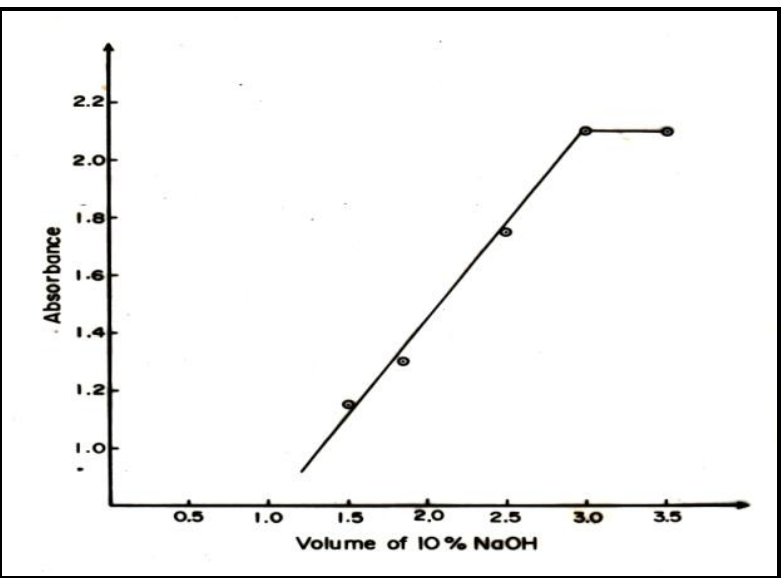

B- EFFECT OF VOLUME OF $10 \% \mathrm{NaOH}$ 


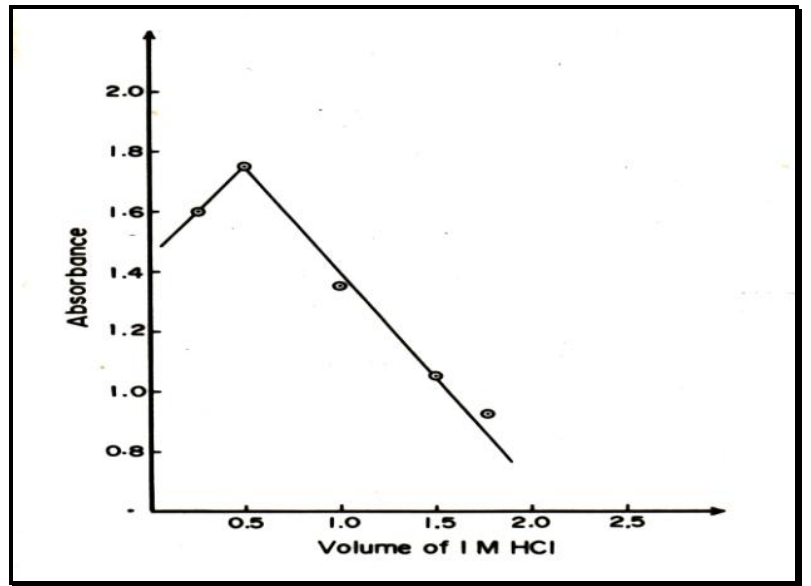

C- EFFECT OF VOLUME OF $1 \mathrm{M}$ HCl

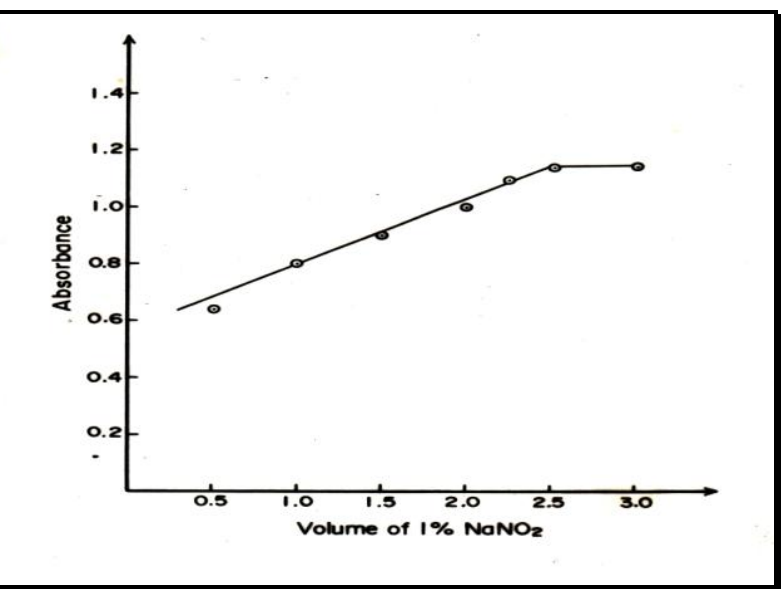

D- EFFECT OF VOLUME OF $1 \% \mathrm{NaNO}_{2}$

FIGURE 2. REACTION CONDITIONS OF THE COLOR FORMATION OF METRONIDAZOLE WITH 2, 5-DIHYDROXY BENZOIC ACID AS A COUPLING AGENT.

\section{Quantifications of Drugs:}

Under the optimum experimental conditions attained, the standard calibration curve as shown in Figures 3 and $\mathbf{4}$ obeyed Beer's law over the Metronidazole and Secnidazole concentration range $(5-50 \mu \mathrm{g} / \mathrm{ml})$ for both drugs in case of 2 , 5dihydroxy benzoic acid.

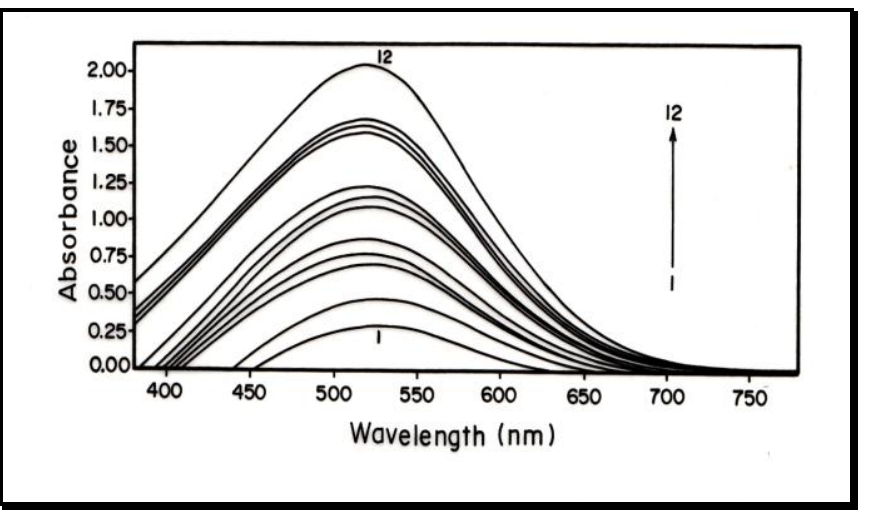

FIGURE 3. ABSORPTION SPECTRA OF SECNIDAZOLE DRUG IN

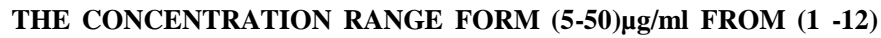
IN PRESENCE OF $1 \mathrm{ml}$ of $1 \mathrm{M} \quad \mathrm{HCl}, 1 \mathrm{ml}$ OF $2 \% \quad 2$, 5 DIHYDROXYBENZOIC ACID, $1 \mathrm{ml}$ of $10 \% \mathrm{NaOH}, 2 \mathrm{ml}$ ETHANOL AND $1 \mathrm{ml}$ of $2 \% \mathrm{NaNO}_{2}$ AT $25^{\circ} \mathrm{C}$

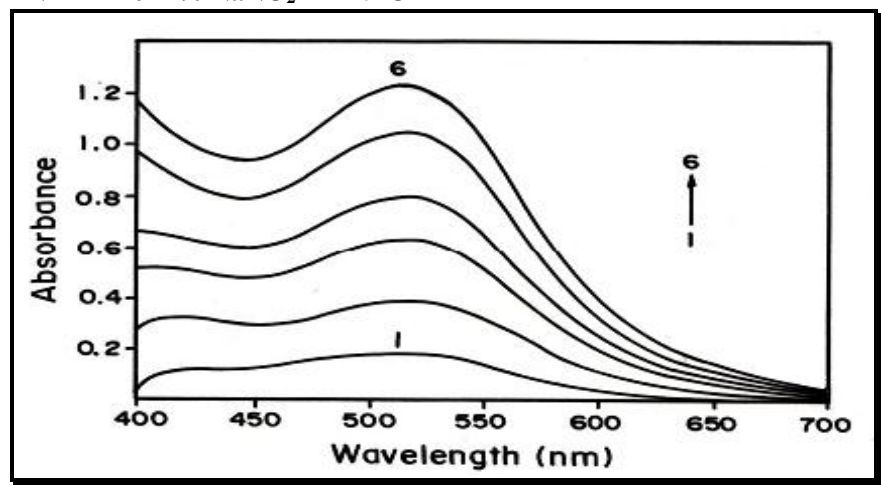

FIGURE 4: ABSORPTION SPECTRA OF METRONIDAZOLE DRUG IN THE CONCENTRATION RANGE FORM $(5-50) \mu \mathrm{g} / \mathrm{ml}$ FROM $(1$ 6 ) IN PRESENCE OF $0.5 \mathrm{ml}$ of $1 \mathrm{M} \mathrm{HCl}, 1 \mathrm{ml}$ of $2 \% \quad 2,5$ DIHYDROXYBENZOIC ACID, $1.5 \mathrm{ml}$ of $10 \% \mathrm{NaOH}, 2 \mathrm{ml}$ ETHANOL AND $1 \mathrm{ml}$ of $2 \% \mathrm{NaNO}_{2} \mathrm{AT} 25^{\circ} \mathrm{C}$
Similarly, Beer's law is obeyed over the metronidazole concentration range $(2-12 \mu \mathrm{g} / \mathrm{ml})$ and over the Secnidazole concentration range (3$30 \mu \mathrm{g} / \mathrm{ml}$ ) in case of $\alpha$-naphthylamine.

The details of optical characteristics were summarized in Tables $\mathbf{1}$ and 2 . It was observed from these Tables that the proposed method was validated by determining various optical parameters, in case of two coupling agents used 2, 5-dihydroxy benzoic acid and $\alpha$ - naphthylamine. It was noticed that the two procedures have been valid for determination of drugs under consideration with two mentioned coupling agents.

TABLE 1: REGRESSION ANALYSIS DATA AND SUMMARY OF PARAMETERS FOR THE SPECTROPHOTOMETRIC DETERMINATION OF METRONIDAZOLE AND SECINDAZOLE USING $\alpha$-NAPHTHYL AMINE AS A COUPLING AGENT

\begin{tabular}{|c|c|c|}
\hline Parameters / characteristics & Secnidazole & $\begin{array}{c}\text { Metronidazol } \\
\text { e }\end{array}$ \\
\hline Colour & Red & Red \\
\hline$\lambda_{\max }(\mathrm{nm})$ & 510 & 510 \\
\hline Stability (in days) & 3 & 3 \\
\hline Beer's law range $(\mu \mathrm{g} / \mathrm{ml})$ & $3-30$ & $2-12$ \\
\hline Ringbom range $\left(\mu \mathrm{g} \mathrm{m}^{-1}\right)$ & $6-27$ & $3-10$ \\
\hline Limit of Detection $(\mu \mathrm{g} / \mathrm{ml})$ & 0.049 & 0.1142 \\
\hline Limit of Quantification & 0.164 & 0.3805 \\
\hline$(\mu \mathrm{g} / \mathrm{ml})$ & $3.56 \times 10^{3}$ & $15.02 \times 10^{3}$ \\
\hline Molar absorptivity (L. mol ${ }^{-1}$ & 0.0529 & 0.0114 \\
\hline $\left.\mathrm{cm}^{-1}\right)$ & -- & -- \\
\hline Sandell's sensitivity $\left(\mu \mathrm{g} \mathrm{cm}^{-2}\right)$ & 0.019 & 0.088 \\
\hline Regression equation $^{\mathrm{a}}$ & 0.127 & 0.055 \\
\hline Slope (a) & 0.9994 & 1.0009 \\
\hline Intercept (b) & 0.1125 & 0.237 \\
\hline $\begin{array}{c}\text { Correlation coefficient } \\
\text { RSD }(\%)^{\mathrm{b}}\end{array}$ & & \\
\hline
\end{tabular}

${ }^{a} y=a x+b$ where $x$ is the conc. of Metronidazole or Secnidazole in $(\mu \mathrm{g} / \mathrm{ml})$

${ }^{\mathrm{b}}$ Ten replicates. 
TABLE 2: REGRESSION ANALYSIS DATA AND SUMMARY OF PARAMETERS FOR THE SPECTROPHOTOMETRIC DETERMINATION OF METRONIDAZOLE AND SECINDAZOLE USING 2, 5-DIHYDROXYBENZOIC ACID AS A COUPLING AGENT

\begin{tabular}{|c|c|c|}
\hline Parameters / characteristics & Secnidazole & Metronidazole \\
\hline Colour & Violet & Violet \\
\hline$\lambda_{\max }(\mathrm{nm})$ & 520 & 518 \\
\hline Stability (in days) & 3 & 3 \\
\hline Beer's law range $(\mu \mathrm{g} / \mathrm{ml})$ & $5-50$ & $5-50$ \\
\hline Ringbom range $\left(\mu \mathrm{g} \mathrm{m}^{-1}\right)$ & $10-45$ & $10-45$ \\
\hline Limit of Detection $(\mu \mathrm{g} / \mathrm{ml})$ & 0.0091 & 0.0214 \\
\hline Limit of Quantification $(\mu \mathrm{g} / \mathrm{ml})$ & 0.0303 & 0.0649 \\
\hline Molar absorptivity (L. $\left.\mathrm{mol}^{-1} \mathrm{~cm}^{-1}\right)$ & $5.8 \times 10^{3}$ & $4.4 \times 10^{3}$ \\
\hline Sandell's sensitivity $\left(\mu \mathrm{g} \mathrm{cm}^{-2}\right)$ & 0.0031 & 0.0114 \\
\hline Regression equation $^{\mathrm{a}}$ & - & - \\
\hline Slope (a) & 0.024 & 0.188 \\
\hline Intercept (b) & 0.683 & 0.319 \\
\hline Correlation coefficient & 0.9997 & 0.9993 \\
\hline $\operatorname{RSD}(\%)^{\mathrm{b}}$ & 0.088 & 0.011 \\
\hline
\end{tabular}

${ }^{\mathrm{a}} \mathrm{y}=\mathrm{a} \mathrm{x}+\mathrm{b}$ where $\mathrm{x}$ is the concentration of metronidazole or secnidazole in $(\mu \mathrm{g} / \mathrm{ml})$

${ }^{\mathrm{b}}$ Ten replicates.

The apparent molar absorptivity $(\varepsilon)$ of the resulting colored product in the proposed method with $\alpha-$ naphthyl amine as a coupling agent was found to be $3.50 \times 10^{3}$ and $15.02 \times 10^{3} \quad$ L.mol ${ }^{-1} \mathrm{~cm}^{-1}$ for
Secnidazole and Metronidazole drugs; respectively as shown in Table 1. A comparison of these values with other values of molar absorptivities obtained in the literature which were $6.60 \times 10^{3}$ and $2.68 \times 10^{3}$ L.mol ${ }^{-1} \mathrm{~cm}^{-1}$ for both Secnidazole and Metronidazole; respectively using $\beta$-naphtol as coupling agent ${ }^{29}$. Also, by comparing the molar absorptivity value $(\varepsilon)$ of the resulting colored product in our proposed method with excellent and new coupling agent 2,5-dihydroxybenzoic acid were found to be $5.8 \times 10^{4}$ and $4.4 \times 10^{4} \mathrm{~L}^{\mathrm{mol}} \mathrm{mol}^{-1} \mathrm{~cm}$ ${ }^{1}$ for Secnidazole and Metronidazole; respectively.

A comparison of our obtained values of molar absorpivities and Beer's law range obtained with other values reported in literature ${ }^{29,30}$ showed that our obtained values could be very satisfactory for the analysis of both Seccnidazole and Metronidazole drugs at concentration levels examined as shown in Table 3.

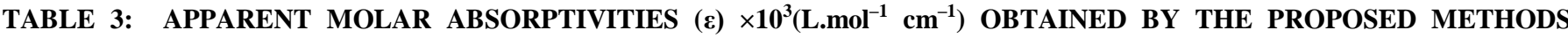
COMPARED WITH OTHER REPORTED METHODS

\begin{tabular}{l|l|l|l|l}
\hline \multirow{2}{*}{ Coupling agent used } & \multicolumn{2}{|l|}{ Value of $(\boldsymbol{\varepsilon}) \times \mathbf{1 0}^{\mathbf{3}}\left(\mathbf{L} \cdot \mathbf{~ m o l}^{-1} \mathbf{c m}^{-\mathbf{1}}\right)$} & \multicolumn{2}{l}{ Beer's law range in $(\boldsymbol{\mu g} / \mathbf{m l})$} \\
\cline { 2 - 5 } & SNZ & MNZ & SNZ & MNZ \\
\hline $\begin{array}{l}\text { B-naphtol [29] } \\
\text { 8-quinolinol [30] }\end{array}$ & 6.60 & 2.68 & $2-30$ & $5-50$ \\
$\begin{array}{l}\alpha \text {-naphthyl amine } \\
\text { (proposed method ) }\end{array}$ & 11.31 & 9.01 & $1-15$ & $1-17$ \\
$\begin{array}{l}\text { 2,5-dihydroxybenzoic acid } \\
\text { (proposed method) }\end{array}$ & 3.50 & 15.02 & $3-30$ & $2-12$ \\
\hline
\end{tabular}

Interferences: A detailed study on the interference of various concomitant substances on the determination of these drugs was made. The extend of interference by various excipients that often accompany the pharmaceutical formulations were tabulated in Table 4. Some of the common excipients, which often accompany the pharmaceutical preparations do not interfere in the proposed method. An error of $2.0 \%$ in the absorbance readings was considered tolerable.

TABLE 4: RECOVERY OF METRONIDAZOLE (MNZ) AND SECNIDAZOLE (SCN) IN PRESENCE OF DIFFERENT EXCIPIENTS USING $\alpha$-NAPHTHYL AMINE AND 2, 5-DIHYDROXYBENZOIC ACID

\begin{tabular}{|c|c|c|c|c|c|}
\hline \multirow{3}{*}{ Excipients } & \multirow{3}{*}{$\begin{array}{l}\text { Amount } \\
\text { (mg) }\end{array}$} & \multirow{2}{*}{\multicolumn{2}{|c|}{$\begin{array}{l}\text { Recovery \% of (MNZ })^{a} \\
\left(\% \pm \text { RSD }^{b}\right) \\
\alpha-\text { naphthyl amine }\end{array}$}} & \multirow{2}{*}{\multicolumn{2}{|c|}{$\begin{array}{l}\text { Recovery \% of (SNZ) }{ }^{\mathrm{a}} \\
\left(\% \pm \mathrm{RSD}^{\mathrm{b}}\right) \\
\text { 2,5-dihydroxybenzoic acid }\end{array}$}} \\
\hline & & & & & \\
\hline & & MNZ & SNZ & MNZ & SNZ \\
\hline Uric acid & 50 & $98.95 \pm 0.36$ & $99.21 \pm 0.73$ & $99.31 \pm 0.71$ & $99.34 \pm 1.26$ \\
\hline Vitamin C & 50 & $99.71 \pm 0.29$ & $98.98 \pm 0.45$ & $97.83 \pm 0.88$ & $99.44 \pm 1.16$ \\
\hline Glucose & 50 & $99.62 \pm 0.26$ & $99.11 \pm 0.74$ & $99.97 \pm 0.34$ & $99.55 \pm 0.93$ \\
\hline Carboxy methyl cellulose & 50 & $99.47 \pm 0.27$ & $99.28 \pm 0.92$ & $98.93 \pm 0.83$ & $99.47 \pm 1.09$ \\
\hline Lactose & 50 & $99.49 \pm 0.35$ & $99.35 \pm 0.15$ & $98.57 \pm 0.72$ & $99.66 \pm 0.72$ \\
\hline Cellulose & 50 & $99.51 \pm 0.33$ & $99.49 \pm 0.18$ & $98.97 \pm 0.71$ & $99.20 \pm 0.82$ \\
\hline
\end{tabular}

${ }^{\mathrm{a}} 10 \mu \mathrm{g} / \mathrm{ml}$ of metronidazole and secnidazole were taken.

${ }^{\mathrm{b}}$ Average of ten determinations. 


\section{Applications:}

The applicability of the spectrophotometric method to assay of pharmaceutical preparations was successfully made; the results were presented in Table 5. The tests showed that results of the proposed methods were very satisfactory compared with other reported methods in literature ${ }^{29-30}$.

The applicability of the suggested methods for the assay of a wide variety of pharmaceutical preparations was examined. The results of the assay of tablets are given in Table 5. The results of the assay of the pharmaceutical preparations were cross checked by the official methods ${ }^{21,29-30}$. The obtained results compared favorably with other data in literature and our obtained results were highly reproducible.

TABLE 5: APPLICATION OF THE PROPOSED METHODS FOR THE DETERMINATION OF METRONIDAZOLE (MNZ) AND SECINDAZOLE (SCN) IN DOSAGE FORM USING $\alpha$-NAPHTHYL AMINE AND 2, 5-DIHYDROXY BENZOIC ACID

\begin{tabular}{|c|c|c|c|c|}
\hline \multirow{2}{*}{$\begin{array}{l}\text { Commercial } \\
\text { formulations Analyzed }\end{array}$} & \multirow{2}{*}{ Content } & \multirow{2}{*}{$\begin{array}{l}\text { Label } \\
\text { Claim (mg) }\end{array}$} & \multicolumn{2}{|c|}{ Recovery $^{\text {a }} \%,\left( \pm\right.$ RSD $\left.^{b}\right)$} \\
\hline & & & $\alpha$-naphthyl amine & 2,5-dihydroxy benzoic acid \\
\hline${ }^{\mathrm{c}}$ Secnidazole ${ }^{(} 500$ & SNZ & $500 /$ tablet & $97.80 \pm 0.52$ & $97.50 \pm 1.01$ \\
\hline${ }^{\mathrm{d}}$ Senidal ${ }^{\circledR} 500$ & SNZ & $500 /$ tablet & $99.72 \pm 0.34$ & $99.33 \pm 0.68$ \\
\hline${ }^{\mathrm{e}}$ Flagyl $^{\circledR} 250$ & MNZ & 250 / tablet & $97.60 \pm 0.83$ & $98.29 \pm 0.58$ \\
\hline${ }^{\mathrm{f}}$ Flagyl $^{\circledR} 500$ & MNZ & $500 /$ tablet & $99.25 \pm 0.48$ & $98.00 \pm 0.58$ \\
\hline
\end{tabular}

a: Average of ten determinations.

b: Relative standard deviation.

c: product of Egyptian Int. pharmaceutical industries CO., Egypt, Batch no. 1305303

d: product of Global Napi pharmaceuticals, Egypt, Batch no. A22506.

e: product of Sanofi Aventis, Egypt, under license of Sanofi Aventis, France, Batch no. 3EG114.

f: product of Sanofi Aventis, Egypt, under license of Sanofi Aventis, France, Batch no. 3EG011.

The excellent recoveries obtained indicated the absence of any interference from the common excipients.

CONCLUSION: The work evidenced that our proposed spectrophotometric methods were found to be simple, selective, economical, rapid and sensitive compared with available spectrophotometric methods in the concentration range of the determination. The statistical parameters and recovery study data clearly indicated the reproducibility and accuracy of the proposed method in the range of the determination concentration. Analysis of the authentic samples containing Metronidazole and Secnidazole showed no interference from the common excipients. Hence, the present work seemed to be very suitable for the analysis of Secnidazole and Metronidazole in tablet dosage forms.

\section{REFERENCES:}

1. Capitan-vallvey LF, Ariza A, Checa R and Navas N: Liquid Chromatography-Mass Spectrometry determination of six 5-Nitroimidazoles in animal feed stuff. Chromatographia 2007; 65:283-290

2. Martindale: The Extra Pharmacopoeia. The Pharmaceutical Press, London, $27^{\text {th }}$ Edition 1977.

3. Hashem EY and Youssef AK: Spectrophotometric determination of norepinephrine with sodium iodate and determination of its acidity constants. Journal of Applied Spectroscopy 2013; 80:266-272.
4. Ghoneim MM, Mabrouk EM, Hassanein AM, El-Attar MA and Hesham EA: Voltammetric and potentiometric studies of some sulpha drup-schiff base compounds and their metal complexes. Centr. Europ. J. Chem. 2007; 5: 898-91.

5. Kattab FI, Ramadan NK, Hegazy MA and Ghoniem NS: Microsized graphite sensors for potentiometric determination of metronidazole and spiramycin. Portugaliae Electro Chimica Acta 2011; 29: 79-90.

6. Ghani NTA, El-Ries MA and El-Shall MA: Validated polarographic methods for the determination of certain antibacterial drugs. Anal. Sci. 2007; 23: 1053-1058

7. El-Sayed GO,Yasin SA and El-Badawy AA: Determination of secnidazole in tablets and human serum by cathodic adsorptive stripping voltammetry. Arabiam Journal of Chemistry 2010; 3:167-172.

8. Wang JH: Determination of three nitroimidazole residues in poultry meat by gas chromatography with nitrogenphosphorus detection. J. Chromatogr. A 2001; 918:435438.

9. Bari Viddesh R, Dhorda UJ and Sundaresan M: Simultaneous estimation of nalidixic and metronidazole in dosage forms using packed column supercritical fluid chromatography. Anal. Chim. Acta 1998; 376:221-225

10. Zarapkar SS and Kanyawar NS: Simutaneous determination of norfloxacin and metronidazole in tablet by HPLC. Indian Drugs 1999; 36:293-295

11. Ouyang LQ and Wu HL: Simultaneous determination of metronidazole and tinidazole in plasma by using HPLCDAD coupled with second-order calibration. Chinese Chemical Letters 2010; 21: 1223-1226.

12. Al Halabi Z, Al-Khayat MA and Haidar S: Separation and assay of antiprotozoal imidazole derivatives (Metronidazole, Tinidazole and Secnidazole) by RPHPLC. International Journal of Pharmaceutical Sciences Review and Research 2012; 13: 13-18.

13. Cronly M, Behan P, Foley B, Malone E and Regan L: Rapid confirmatory method for the determination of 11 nitroimidazoles in egg using liquid chromatography 
tandem mass spectrometry. Journal of Chromatography A 2009; 1216: 8101-8109.

14. Nora $\mathrm{H}$ and Al-Shaalan: Determination of diloxanide Furoate and metronidazole in binary mixture using first derivative of the ratio-spectra and high-performance liquid chromatography-UV methods. Amer. J. Appl. Sci. 2007; 4: 66-72.

15. Liu W, Zhang J, Li C, Tang L, Zhang Z and Yang M: A novel composite film derived from cysteic acid and PDDA-functionalized grapheme. Enhanced sensing material for electrochemical determination of metronidazole. Talanta 2013; 104: 204-211.

16. Vega E and Sola N: Quantitative analysis of metronidazole in intravenous admixture with ciprofloxacin by first derivative spectrophotometry. J. Pharm. Biomed. Anal. 2001; 25:523-530.

17. Karpinska J: Derivative spectrophotometry-recent applications and directions of developments. Talanta 2004; 64:801-822.

18. Sastry CSP and Naidu PY: Spectrophotometric determination of astemizole. Talanta 1998; 45:795-799.

19. Palomeque M, Garcia Bautista JA, Garcia Mateo JV and Martinez Calatayud J: Flow injection biamperometric determination of metronidazole with on-line photodegradation. J. Anal. Chim. Acta 1999; 401:229-236.

20. Maheshwari RK, Rajput MS and Sinha S: Ecofriendly spectrophotometric estimation of tinidazole in tablets using lignocaine hydrochloride as a hydrotropic solubilizing agent. Asian J. Pharm. 2009; 3: 319-321.

21. El Walily A, Abdine HH, Abdel Razak O and Zamel S: Spectrophotometric and HPLC determination of secnidazole in pharmaceutical tablets. J. Pharm. Biomed. Anal. 2000; 22:887-897.

22. Thulasamma P and Venkateswarlu P: Spectrophotometric method for the determination of metronidazole in pharamaceutical pure and dosage forms. Rasayan J. Chem. 2009; 2: 865-868.
23. Adegoke OA and Umoh OE: A new approach to the spectrophotometric determination of metronidazole and tinidazole using P-dimethylaminobenzaldehyde. Acta Pharm. 2009; 59: 407-419.

24. Maliwal D, Jain A, Maheshwari RK and Patidar V: Simultaneous spectrometric estimation of metronidazole and norfloxacin in combined tablet formulations using hydrotropy. Res. J. Pharm. and Tech. 2008; 1: 357-361.

25. Abul Khier A, El Henawee MM and El Masry MS: Spectrophotometric method for the determination of some drugs using Fast Red B Salt. E. J. Chem. 2008; 5:10871097.

26. Jafari MT, Rezaei B and Zaker B: Ion Mobility spectrometry as a detector for molecular imprinted polymer separation and metronidazole determination in pharmaceutical and human serum samples. Anal. Chem. 2009; 18: 3585-3591.

27. Darwish KM, Salama F and Mostafa El-Sadek M: Extractional spectrophotometric analysis of metronidazole, tinidazole, ornidazole and secnidazole bases through aciddye complexation using bromothymol blue dye. Pak. J. Pharm. Sci. 2012; 25:207-217.

28. Mishra AK, Kumar A, Mishra A and Mishra HV: Development of ultraviolet spectroscopic method for the estimation of metronidazole benzoate from pharmaceutical formulation. J. Nat. Sc. Biol. Med. 2014; 5: 261-264.

29. Saffaj T, Charrouf M, Abourriche A, Aboud Y, Beenamara A, and Berrada M: Spectrophotometric determination of metronidazole and secnidazole in pharmaceutical preparations based on the formation of dyes. Dyes and Pigments 2006; 70:259-262.

30. Saffaj T, Charrouf M, Abourriche A, Aboud Y, Beenamara A and Berrada M: Spectrophotometric determination of metronidazole and secnidazole in pharmaceutical preparations. Farmaco 2004; 59:843-846.

How to cite this article:

Youssef AK, Saleh MSS, Abdel-Kader DA and Hashem EY: Facile Spectrophotometric Determination of Metronidazole and Secnidazole in Pharmaceutical Preparations Based On the Formation of Dyes. Int J Pharm Sci Res 2015; 6(1): 103-10.doi: 10.13040/IJPSR.0975-8232.6 (1).103-10.

All @ 2013 are reserved by International Journal of Pharmaceutical Sciences and Research. This Journal licensed under a Creative Commons Attribution-NonCommercial-ShareAlike 3.0 Unported License.

This article can be downloaded to ANDROID OS based mobile. Scan QR Code using Code/Bar Scanner from your mobile. (Scanners are available on Google Playstore) 